Portland State University

PDXScholar

\title{
The Development of Low-/No-Emission Electric Vehicle Infrastructure in the Portland Metro Region: A Roadmap
}

John MacArthur

Portland State University

Peter Murchie

$E P A$

George Beard

Portland State University

Follow this and additional works at: https://pdxscholar.library.pdx.edu/trec_reports

Part of the Transportation Commons, Urban Studies Commons, and the Urban Studies and Planning Commons

Let us know how access to this document benefits you.

\section{Recommended Citation}

MacArther, John, Peter Murchie and George Beard. The Development of Low-/No-Emission Electric Vehicle Infrastructure in the Portland Metro Region: A Roadmap. OTREC-ED-08-01. Portland, OR: Transportation Research and Education Center (TREC), 2014. https://doi.org/10.15760/trec.42

This Report is brought to you for free and open access. It has been accepted for inclusion in TREC Final Reports by an authorized administrator of PDXScholar. Please contact us if we can make this document more accessible: pdxscholar@pdx.edu. 


\section{S) OTREC}

FINAL REPORT

The Development of Low-/No-Emission Electric Vehicle Infrastructure in the Portland Metro Region: A Roadmap

OTREC-ED-08-01

June 2014 



\section{THE DEVELOPMENT OF LOW-/NO-EMISSION ELECTRIC VEHICLE INFRASTRUCTURE IN THE PORTLAND METRO REGION: \\ A ROADMAP}

Final Report

OTREC-ED-08-01

by

John MacArthur

Portland State University

for

Oregon Transportation Research

and Education Consortium (OTREC)

P.O. Box 751

Portland, OR 97207

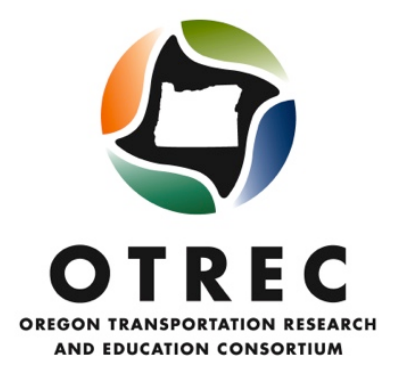

June 2014 



\begin{tabular}{|c|c|c|c|c|c|}
\hline \multicolumn{6}{|c|}{ Technical Report Documentation Page } \\
\hline 1. Report No. & \multicolumn{3}{|l|}{ 2. Government Accession No. } & \multicolumn{2}{|c|}{ 3. Recipient's Catalog No. } \\
\hline \multicolumn{4}{|l|}{ 4. Title and Subtitle } & \multicolumn{2}{|c|}{ 5. Report Date } \\
\hline \multicolumn{6}{|c|}{$\begin{array}{l}\text { THE DEVELOPMENT OF LOW-/NO-EMISSION ELECTRIC VEHICLE INFRASTRUCTURE } \\
\text { IN THE PORTLAND METRO REGION: A ROADMAP }\end{array}$} \\
\hline & & & & \multicolumn{2}{|c|}{ 6. Performing Organization Code } \\
\hline \multicolumn{4}{|l|}{ 7. Author(s) } & \multirow{2}{*}{\multicolumn{2}{|c|}{ 8. Performing Organization Report No. }} \\
\hline \multicolumn{4}{|l|}{ John MacArthur } & & \\
\hline \multirow{2}{*}{\multicolumn{4}{|c|}{ 9. Performing Organization Name and Address }} & \multicolumn{2}{|c|}{ 10. Work Unit No. (TRAIS) } \\
\hline & & & & \multicolumn{2}{|c|}{ 11. Contract or Grant No. } \\
\hline \multicolumn{4}{|l|}{ 12. Sponsoring Agency Name and Address } & \multicolumn{2}{|c|}{ 13. Type of Report and Period Covered } \\
\hline \multicolumn{4}{|c|}{$\begin{array}{l}\text { Oregon Transportation Research and Education Consortium (OTREC) } \\
\text { P.O. Box } 751 \\
\text { Portland, Oregon } 97207\end{array}$} & \multicolumn{2}{|c|}{ 14. Sponsoring Agency Code } \\
\hline \multicolumn{6}{|c|}{ 15. Supplementary Notes } \\
\hline \multicolumn{6}{|l|}{ 16. Abstract } \\
\hline \multicolumn{6}{|c|}{$\begin{array}{l}\text { Because of significant improvements in car battery technology, the major car manufacturers have brought plug-in vehicles, hybrid electric } \\
\text { and/or all electric to the market over the last four years. Many communities around the country are working to accelerate the adoption of plug-in } \\
\text { vehicles. Communities in Oregon and the Pacific Northwest have led the nation in developing electric vehicle (EV) infrastructure to support the } \\
\text { deployment of EVs and creating a collaborative effort for planning, outreach and policy development. As a pioneering community, the region } \\
\text { has translated a deeper understanding of the challenges and barriers to implementing the needed EV infrastructure and shared best practices and } \\
\text { lessons learned with other regions and cities. Four years since the launch of the second generation of U.S. EV deployment, cities and regions are } \\
\text { still struggling with the question of how to get more people to drive EVs and how a city or state becomes EV ready. Currently, there are only } \\
\text { about 4,000 plug-in EVs registered in Oregon, but within a decade plug-in cars could account for as much as } 20 \text { percent of new vehicles sold in } \\
\text { Oregon. This project supported the process of developing a statewide "roadmap" plan and building a partnership coalition. }\end{array}$} \\
\hline $\begin{array}{l}\text { 17. Key Words } \\
\text { Transportation Electrification, Electric }\end{array}$ & es, EV & $\begin{array}{r}\text { 18. D } \\
\text { No } \\
\text { WW }\end{array}$ & $\begin{array}{l}\text { ibution St } \\
\text { rictions. } \\
\text { trec.us }\end{array}$ & $\begin{array}{l}\text { atement } \\
\text { Copies ava }\end{array}$ & REC: \\
\hline $\begin{array}{l}\text { 19. Security Classification (of this report) } \\
\text { Unclassified }\end{array}$ & $\begin{array}{l}\text { 20. Security Classification (of } \\
\text { Unclassified }\end{array}$ & page) & 21. No. & of Pages & 22. Price \\
\hline
\end{tabular}





\section{ACKNOWLEDGEMENTS}

The author thanks the Oregon Transportation Research and Education Consortium (OTREC) for providing the necessary funding support to carry out this research. The author would also like to thank all of the partners in Oregon for their assistance and collaboration on this project and the survey. The author acknowledges the collaboration and assistance from Peter Murchie, Kevin Bannister and Therese Hampton with the National Policy Consensus Center, and George Beard and April Cutter at Portland State University. The author and the project team also acknowledge all of the partners who provided input and collaborated in the overall effort. There are too many organizations to list here, but special acknowledgement is needed for the following: Rocky Mountain Institute (RMI) Project Get Ready, The Lemelson Foundation, Business Oregon, Oregon Department of Transportation, Oregon Department of Energy, Metro, the City of Portland, Multnomah County, Drive Oregon and Portland General Electric. Any error, mistake or omission related to this research paper is the sole responsibility of the authors.

\section{DISCLAIMER}

The contents of this report reflect the views of the authors, who are solely responsible for the facts and the accuracy of the material and information presented herein. This document is disseminated under the sponsorship of the U.S. Department of Transportation University Transportation Centers Program and OTREC in the interest of information exchange. The U.S. Government and OTREC assume no liability for the contents or use thereof. The contents do not necessarily reflect the official views of the U.S. Government or OTREC. This report does not constitute a standard, specification, or regulation. 


\section{TABLE OF CONTENTS}

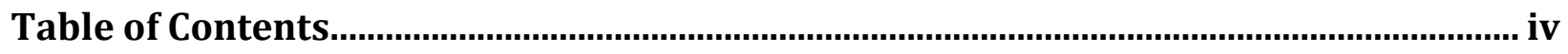

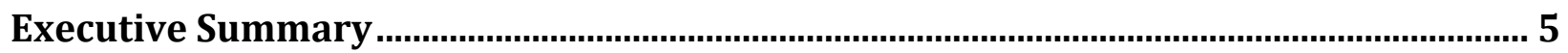

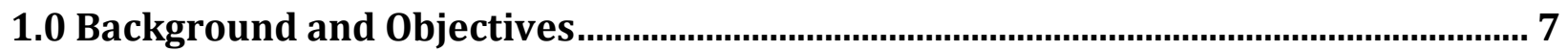

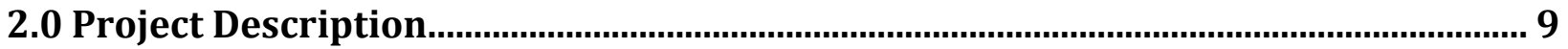

3.0 Outcome and Results ....................................................................................................11

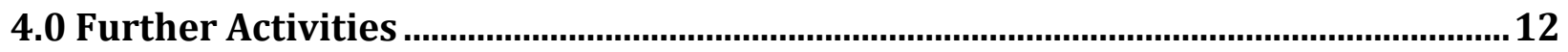

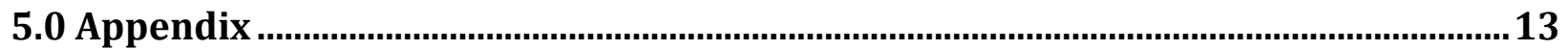




\section{EXECUTIVE SUMMARY}

Because of significant improvements in car battery technology, the major car manufacturers have brought plug-in vehicles, hybrid electric and/or all electric to the market over the last four years. Many communities around the country are working to accelerate the adoption of plug-in vehicles. Communities in Oregon and the Pacific Northwest have led the nation in developing electric vehicle (EV) infrastructure to support the deployment of EVs and creating a collaborative effort for planning, outreach and policy development. As a pioneering community, the region has translated a deeper understanding of the challenges and barriers to implementing the needed EV infrastructure and shared best practices and lessons learned with other regions and cities. Four years since the launch of the second generation of U.S. EV deployment, cities and regions are still struggling with the question of how to get more people to drive EVs and how a city or state becomes EV ready. Currently, there are only about 4,000 plug-in EVs registered in Oregon, but within a decade plug-in cars could account for as much as 20 percent of new vehicles sold in Oregon. This project supported the process of developing a statewide "roadmap" plan and building a partnership coalition.

This project helped support the creation of a "roadmap" for the development of vehicle infrastructure and vehicle deployment in the state. These efforts have helped guide research, education, partnership initiatives and community engagement activities at Portland State University (PSU), the Oregon University System (OUS) and the Portland Metro region. The roadmap has become the basis for the creation of the Energize Oregon Coalition. The project helped build momentum on a number of efforts including the Governor's Alternative Fuels Infrastructure Working Group, the creation and support of the Governor's Transportation Electrification Executive Committee (TEEC), local utility and international automotive industry interest in Portland, and other national efforts through the U.S. Department of Transportation and the U.S. Department of Energy. This effort was truly a multidisciplinary, multipartner and multicampus focus and effort. The project focused on developing a unifying strategy, plan, knowledge base for low- and no-emission vehicles, alternative fuels infrastructure and other sustainable mobility innovations.

This project created or supported the development of the following:

1. NPCC Assessment for the Oregon Electric Vehicle Executive Council and Collaborative Action Roadmap

2. Transportation Electrification Executive Council (TEEC)

3. Declaration of Cooperation Energizing Oregon Transportation Electrification Executive Council

4. Energize Oregon Coalition

5. EVRoadmap.us statewide website

6. The annual EV Roadmap conference

7. Energize Oregon Community Readiness Plan

8. EV Readiness and Deployment Survey for the Portland Metro Region report 
9. Driving Adoption of Electric Vehicles to the Early Majority report 


\subsection{BACKGROUND AND OBJECTIVES}

During the last four years, Oregon has become a national leader in transportation electrification through important events and activities in the state, and the development of important national relationships with the auto industry and electric vehicle (EV) charging companies. Because of the comprehensive and collaborative planning, effort and strategy, Oregon has been able to seize the opportunity to become the national leader in the adoption and incorporation of new vehicle platforms and mobility strategies into the fabric of urban life and the built environment. Oregon is currently actively engaged in relationships with international automotive companies and local businesses and utilities interested in being part of the "Oregon Experiment."

Electric mobility combines innovative business models with infrastructure and breakthrough technologies to support the use of EVs in densely populated areas. It includes transformational concepts in mobility such as car-sharing programs, charging infrastructures, city planning projects and smart technologies. Major car companies launch and test their latest EVs in Oregon, which has the most DC fast-charging stations in the country. And, Oregon policy continuously pushes boundaries by launching creative pilot projects and deployment activities to advance electric mobility.

Since 2010, the Oregon Department of Transportation (ODOT) and Oregon Department of Energy (ODOE) have supported several projects around the state focused on EVs and EV charging infrastructure that have been key in the development of the state's strategic vision, including the following:

- The EV Project run by ECOtality aimed at supporting widespread adoption of the technology.

- EV DC fast-charge stations along Interstate 5, the West Coast's busiest north-south route, part of the West Coast Green Highway infrastructure building efforts.

- Tiger II Grant for EV infrastructure, funding 33 EV fast-charging stations throughout Oregon, along key corridors such as Oregon’s coast, the Columbia Gorge and the Cascades.

These and future projects are helping Oregon create a sustainable transportation system by reducing the state's reliance on imported petroleum and by reducing greenhouse gas emissions.

This project helped support the creation of a "roadmap" for the development of vehicle infrastructure and vehicle deployment in the state. These efforts have helped guide research, education, partnership initiatives and community engagement activities at Portland State University (PSU), Oregon University System (OUS) and the Portland Metro region. The roadmap has become the basis for the creation of the Energize Oregon Coalition. The project helped build momentum on a number of efforts including the Governor's Alternative Fuels Infrastructure Working Group, the creation and support of the Governor's Transportation Electrification Executive Committee (TEEC), local utility and international automotive industry interest in Portland, and other national efforts through the U.S. Department of Transportation and the U.S. Department of Energy. This effort was truly a multidisciplinary, multipartner and multicampus focus and effort. The project focused on developing a unifying strategy, plan, knowledge base for low- and no-emission vehicles, alternative fuels infrastructure and other sustainable mobility innovations. 
The specific objectives for this project were to:

1) Strengthen and broaden strategic partnerships that will provide financial and other continuing research, education and community engagement opportunities in EV infrastructure.

2) Develop a strategic roadmap for Portland and the state of Oregon to achieve plug-in readiness and to enhance EV deployment.

3) Develop a comprehensive research agenda to evaluate a wide array of research and testing needs for the region.

4) Coordinate with national efforts through the Rocky Mountain Institute's Project Get Ready, sharing knowledge with other participating Project Get Ready cities, national Clean Cities programs and other national efforts. 


\subsection{PROJECT DESCRIPTION}

This project was a joint effort between OTREC and the Hatfield School of Government through the National Policy Consensus Center's (NPCC) Oregon Solutions program and the Executive Leadership Institute. This project also relied on partnerships with other local, state and national organizations.

Methods included a thorough literature review (print and web); an inventory of local municipalities' and state agencies' actions; interviews with key partners; and a consensus building initiative. NPCC's Oregon Solutions program used its expertise and experience in collaborative governance practices to bring diverse stakeholders to the table to inform, develop and initiate the implementation of the roadmap. Oregon Solutions staff engaged in information collection, interviews and other efforts to assess the interests and resources of the project partners, refine the vision, and design and support the collaborative convening for the project. This included developing agendas, products and materials; providing facilitation; note taking; and post-meeting follow up leading to a declaration of cooperation that will codify the individual and group commitments, roles and responsibilities for implementing the roadmap. Appendix $\mathrm{A}$ is the NPCC Assessment for the Oregon Electric Vehicle Executive Council and Collaborative Action Roadmap.

In September 2010, Governor Kulongoski established the Transportation Electrification Executive Council (TEEC) (EO 10-09). Governor Kitzhaber endorsed the Council in March 2012. The Council's objective was to focus and coordinate public, private and civic leadership in ensuring that Oregon is well-positioned to capitalize on the economic benefits of transportation electrification. The TEEC then created a Declaration of Cooperation Energizing Oregon Transportation Electrification Executive Council to help guide the activities of the state (Appendix B).

In June 2011, Business Oregon, with the support of the TEEC, submitted and was awarded a grant to develop a statewide plug-in electric vehicle (PEV) market and community plan. The TEEC served as the steering committee for the project, providing guidance and oversight of both its development and execution. The Energizing Oregon project team used four primary work groups to conduct research, develop plans and make recommendations, focused in four key areas: Deployment, Policy, Outreach and Utilities. NPCC Oregon Solutions staffed the TEEC and OTREC provided strategic guidance and knowledge support during the development of the roadmap process. The final plan was submitted to U.S. DOE in November 2012.

The final Energize Oregon Plan: A Community Readiness Plan includes a list of recommendations to be implemented within the state in order to support the deployment of PEVs in Oregon. This document captures the commitments that entities are willing to make based on their current personnel and financial resources (ready for implementation). In addition, the document captures the commitment of some entities to identify and pursue additional sources of funding to support recommendations that require funding for implementation. 
The creation of the Declaration of Cooperation and the Energize Oregon Plan has now morphed into the Energize Oregon Coalition (www.driveoregon.org/lead/with-the-energize-oregoncoalition). The Coalition, co-chaired by ODOT and Drive Oregon, is a board group of local, regional and national organizations focused on the implementation of the Energize Oregon Plan, with a particular focus on the increased deployment of EVs in Oregon.

During the activities of the roadmap process, OTREC at PSU conducted a comprehensive review of the research capabilities of the university and the Oregon University System. The project team created a concept for an OUS Program Office (Appendix C: Oregon's Program Office for Sustainable Mobility) and the development of a strategic research plan (Appendix D - The Future of Urban Mobility: Portland State University’s Transportation Electrification Initiative Strategic Plan) research agenda to evaluate a wide array of research and testing needs for the region. Both of these efforts served as the platform to launch a boarder OUS-focused effort for OTREC called the Transportation Electrification Initiative (TEI).

The Initiative is a multicampus, multidisciplinary collaboration consisting of PSU, the University of Oregon and the Oregon Institute of Technology. Each campus has established an Initiative point person, who coordinates local campus efforts and outreach. These individuals are working together to develop an overall strategic business plan. The Initiative is a partnership based on enlisting faculty, students, stakeholders, cities, agencies, organizations, utilities and EV-related companies to deliver multidisciplinary solutions for real-world problems. The Initiative works to develop and expand research, education and technology transfer activities, and attract and develop new leaders in the EV field. 


\subsection{OUTCOME AND RESULTS}

The roadmap that was developed in Oregon is not a monolithic, fixed plan. Instead, it is a continuous and dynamic enterprise guided by discovery, partnerships, communication, publicopinion research in Oregon and beyond, and a portfolio of well-selected projects. Below is a list of events and activities that have resulted from this effort.

EVRoadmap.us website:

The purpose of this website is to provide information to community leaders, businesses and consumers that will help them participate in making Oregon the leading place in North America for the introduction of EVs. The website aims to increase the visibility and understanding of EVs through outreach and education to engage all facets of the EV community - early adopters, installers of charging stations, would-be drivers and the merely curious. We share lessons learned and best practices.

EV Roadmap Conferences (evroadmapconference.com):

The EV Roadmap series of workshops (in 2014 the seventh conference will take place) has established itself as the Pacific Northwest's premier EV gathering and one of the leading EV conferences in the United States. The EV Roadmap workshop series brings together Oregon's early adopters with national and international experts to inform transportation electrification efforts across the nation. PSU and Portland General Electric (PGE) have been the primary conference sponsors, but in 2013 Drive Oregon was brought as a primary sponsor. These conferences host between 150-200 people.

Other products developed to support the effort:

1. Energize Oregon Community Readiness Plan: evroadmap.us/sites/default/files/Final_Energizing_Report.pdf

2. EV Readiness and Deployment Survey for the Portland Metro Region: http://optinpanel.org/wp-content/media/Metro_Opt_In_-_12_EV_Survey-March1.pdf

3. Driving Adoption of Electric Vehicles to the Early Majority: otrec.us/files/OTREC_EV_Early_Majority_Report_(Nov_2011).pdf 


\subsection{FURTHER ACTIVITIES}

During the last couple years, Oregon has become an active player in the EV arena, with a number of promising relationships and activities in the early stages of development. Oregon can help the rest of the country in adopting and incorporating new vehicle types as part of a larger quest for sustainable mobility. While the momentum around EVs is promising, the fact of the matter is that we know little about is what is involved in the infrastructure needs and public perception of EVs. What roles and responsibilities does an organization have for EV fleet management? What kind of institutional support and commitment will it take to make the adoption of EVs successful? Are there insurance, regulatory and/or statutory barriers that could impede the deployment of EVs? What performance measures should be developed and tracked for gauging the success of EVs and their adoption? Are there governance issues (policy, fiscal, infrastructure) that state and local governments need to address in the next year or two to ensure success for EV fleet operators and consumers in the future? These are but a few of the questions that should be pursued and cataloged in the next couple years. OTREC will continue to support research and education activities through the Transportation Electrification Initiative. The TEI and OUS campuses are members of the Energize Oregon Coalition, and will provide information and knowledge support to the partners of the coalition. 


\subsection{APPENDIX}

Appendix A: Assessment for the Oregon Electric Vehicle Executive Council and Collaborative Action Roadmap

Appendix B: Declaration of Cooperation: Energizing Oregon Transportation Electrification Executive Council December 2012

Appendix C: Oregon’s Program Office for Sustainable Mobility

Appendix D: The Future of Urban Mobility:

Portland State University's Transportation Electrification Initiative Strategic Plan 


\section{Appendix A}

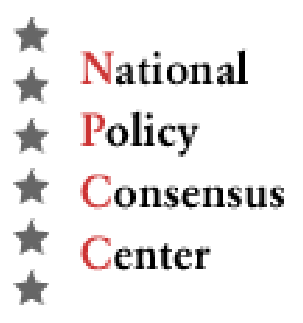

\section{Assessment for the Oregon Electric Vehicle Executive Council and Collaborative Action Roadmap July 2010}

\section{Background}

The assessment of and support for the Oregon Electric Vehicle Collaborative Action Roadmap and the potential EV Executive Council is a joint effort between Oregon Transportation Research and Education Consortium (OTREC) and the Hatfield School of Government through the Executive Leadership Institute (ELI) and the National Policy Consensus Center (NPCC).

ELI is providing the overall leadership for the Initiative. OTREC has contributed funding for the Initiative and has overall responsibility for developing a coordinated decision knowledge base, research and evaluation. NPCC is performing an assessment of the need for and potential design of collaborative support for the 'Roadmap' - EV Executive Council (as recommended by the Alternative Fuel Vehicle Work Group). The Lemelson Foundation and Portland State University (President's Office and Miller Center for Sustainable Practices Grant) have also contributed generously to the Initiative.

George Beard of PSU-ELI, John MacArthur of OTREC and Peter Murchie of NPCC/Oregon Solutions have been speaking with leaders and participants who will play crucial roles in assuring the readiness of the region for the introduction of EV's to the market in late 2010 and beyond.

On Nov. 9, 2009, Portland State University and Portland General Electric, with support from OTREC and the Lemelson Foundation, hosted a daylong EV Roadmap event at the World Trade Center attended by 180 potentially interested and significant players from Oregon and around the Northwest. An Action Roundtable of many of these participants was held on January 7, 2010 to maintain momentum and to further refine issues and potential solutions.

The Federal stimulus package enacted in 2009 by the American Recovery and Reinvestment Act (ARRA) has funded a national company, ECOtality, to install the first charging stations by the end of 2010, when Nissan intends to introduce the all-electric Leaf to the Portland and other markets. 


\begin{abstract}
Vision
Through a collaborative public, private and civic effort led by the EV Executive Council chartered/convened by the Governor (through an Executive Order) create a comprehensive Roadmap and support integrated investments and decision making for the development and implementation of electric vehicle (EV) infrastructure in Oregon. The Council's Roadmap will steer a statewide strategic vision, identify and support implementation opportunities research, education, and partnership initiatives.
\end{abstract}

The EV Executive Council will:

1. Develop a strategic Roadmap for the Willamette/Columbia Region to achieve plug-in readiness in the next two years.

2. Strengthen and broaden strategic partnerships that will provide financial and other continuing research/evaluation, education, and community engagement opportunities in EV infrastructure.

a. Identify the structures, authorities and resources for implementation of EV infrastructure

b. Identify and resolve issues that might impede readiness within two years

c. Create a comprehensive evaluation and research agenda that can provide expertise to evaluate and document the implementation activities for the Region.

3. Integrate decision making and investments in collaborative implementation of EV projects, including launching pilots as needed

4. Coordinate with state, regional, national and international efforts

a. Prioritize coordination with similar efforts in the Pacific Northwest..

b. Create replicable models for implementation, data collection and management and evaluation in other geographic areas.

\title{
Opportunity/Need
}

The Roadmap project presents a significant opportunity to the Region to be in the forefront of advancing one of the signature technologies of the $21^{\text {st }}$ century. The economic and technological development implications of being first to adopt transportation electrification are potentially great. However the Roadmap project will be challenging to implement at the speed necessary, in part because of the number of jurisdictions, participants and issues involved and because of the need to align resources, planning, policies, and logistics. A deliberative and inclusive, yet quick and nimble, process will be required. Oregon fortunately has developed an innovative niche for assisting complex, collaborative decision-making in the context of highly sophisticated urban planning.

\section{Conclusions}

Based on the interviews, the EV Roadmap event and the EV Action Roundtable, and the recommendations from the Alternative Fuel Vehicles Work Group we have concluded that:

- An Electric Vehicle Executive Council (public/private/civic) that can provide high level collaborative decision making on strategic direction, resources, and implementation support is needed;

o One part of the success to date for Oregon on EV is the strength of the existing public/private/civic collaborative approach. All agree that more formally 
chartering (through the Governors office) and strengthening this collaborative effort is necessary to continue our national leadership;

o Because no one authority or organization is responsible for EV in the state, there is a need to create a body - convened by the Governor - with the stature and perspective to chart Oregon's course on EV;

o The University, 'under the auspices of the 'Executive', is and can continue to provide secretariat support for the Executive Leadership Group/Roadmap that combines both neutral collaborative staffing (National Policy Consensus Center) and 'knowledge base' -- data, information, analysis, research/evaluation support (OTREC/ELI in partnership with relevant folks in ODOT and other research/evaluation organizations)

- PSU/OTREC has resources through its grants to provide initial secretariat staffing support for the EV Executive Council/Roadmap;

- PSU/OTREC has greater ability to access and distribute foundation and corporate resources on behalf of the Executive Council/Roadmap;

- There is broad agreement on the EV vision for the state; the need for a Roadmap; and for leveraging/building on the immediate implementation of the ARRA funded charging stations;

- Speed is important as there are many time sensitive opportunities/needs ongoing that could be better taken advantage of with a more formalized collaborative effort under the Governor's auspices;

- The key supporters/champions for the Roadmap and initial project(s) have been identified.

\section{Suggested Next Steps}

- A neutral body with needed leadership/stature should be chartered/convened by the Governor as soon as possible to steer the EV Roadmap development that will support successful first year implementation of the ARRA funded charging stations and other projects and assure broader plug in readiness within two years - EV Executive Council

- The EV Executive Council will meet to refine the vision, develop overall strategy and create workgroups to develop agreements on implementing important tasks, building on the ARRA project.

- The Council will continue work with the Governor's office and Washington counterparts to develop a potential MOU of shared principles and mutual support for EV

Potential Oregon EV Executive Council: Convener, Sponsors, Chairs and Team Members Convener/SuperConvener: Governor

Sponsors: Governor's Office, ODOT, Municipalities/local governments (Portland, Corvallis, Eugene, Salem, Metro, Multnomah County); PGE, EWEB; OR Business; PDC

Roadmap Executive Leadership Chairs:

- Gail Achtermann (OTC)

- Charlie Alcock (PGE)

- Mayor Charlie Tomlinson (Corvallis)

- Duncan Wyse (OBC)

- Joe Cortright (Impressa) 
- Wim Wievel (President PSU)

- Matt Garrett (ODOT)

- Jeff Cogen (Multnomah County)

Roadmap Executive Leadership Members (preference to keep small with work groups that are larger):

- Gail Achtermann (OTC)

- Mayor Charlie Tomlinson (Corvallis)

- Duncan Wyse (OBC)

- Joe Cortright (Impressa)

- Weiden and Kennedy (marketing) and/or Brian Gard (PR/Communications)

- Charlie Allcock (PGE)

- Chris Warner (Governors Office)

- Adam Davis (DH)

- City of Portland (Mayor represented by James Mast PDC)

- Blazers (J. Isaac/Justin Z.)

- League of OR Cities

- Bob Caldwell (OR Editorial Page)

- PUC Staff member

- Metro (Michael Jordan or Andy Cotugno or Council member)

- Jennifer Dill (OTREC Executive Director)

- Jeff Cogen (Multnomah County)

- Eric Lemelson

- Bill Wyatt (Port of Portland)

- Andrea Durbin (OEC) 
Individual Assessment Interviews

Oregon Governor's Office: Chris Warner

Multnomah County: Jeff Cogen

Oregon Transportation Commission: Gail Achtermann

Utilities: Kyle Davis PPL Peter Cogswell BPA, Charlie Alcott PGE, Jeanine Parisi EWEB)

ODOT: Jim Whitty and Art James

ODOE: Rick Wallace

Oregon Business: Mark Brady

Portland Development Commission: James Mast

OTREC: Jennifer Dill

City leadership (Eugene, Salem, Corvallis, Portland)

Metro

OEMs Nissan, Toyota, Ford, Mitsubishi

ECOtality

Oregon Business Council: Duncan Wyse

Angus Duncan: OGWC / Bonneville Environmental Foundation

Eric Lemelson: OGWC / Lemelson Foundation

Bob Parker: University of Oregon

OEC: Andrea Durbin and Chris Hagerbaumer

Roundtable/Summit Meetings (included assessment questions/purposes)

November Summit (over 150 key players including many above)

January 'Kitchen Cabinet'

Nuin-Tara Key Metro (climate specialists)

Katia Dillmann Mayor Adams office

James Mast PDC (EV Economic Development Czar for City of Portland)

Robert Chandler City of Salem Public Works (Assistant Manager)

Roger Kuhlman Salem Electric (18 electric coop)

Charlie Allcock PGE Economic Development Director

April Cutter PSU (research assistant)

George Beard PSU ELI

Mayor Charlie Tomlinson Corvallis

Chris Warner OR Governors Office (Gov point person on EV implementation

Warren Fish Multnomah County Commissioner Jeff Cogen Office (Alt)

Adam Davis (survey of attitudes on EV and findings)

Melissa Wilmont Gard Communications (communications perspective)

Karen Thompson PSU (research and contracts - legal rainmaker and dealmaker)

Jeanine Parisi (EWEB - convening folks for EV)

Deb Bryant OSU Open Source Labs

Alex Bejarano Portland BOT

Mark Brady OR Business Development 


\section{Appendix B}

DECLARATION OF COOPERATION: Energizing Oregon Transportation Electrification Executive Council December 2012 


\section{Appendix C}

\section{Oregon’s Program Office for Sustainable Mobility}

In recent months, Oregon has developed formal relationships with Nissan and Mitsubishi as well as an informal one with Toyota. During the same period, a broad range of public, private, and nonprofit enterprises has come together to work on preparations for plug-in electric vehicles and the infrastructure to support them. This progress has been driven by leadership from the office of the Governor and Oregon DOT, and from key political and business leaders in the Portland region, with particular recognition due to PGE. The progress has also been propelled by a large and growing number of institutional and individual players who are keenly interested in contributing to the transition to cleaner vehicles.

\section{$\underline{\text { Some Questions }}$}

While the headway has been laudable, one could argue that Oregon's aspirations and migration toward new vehicle platforms and infrastructure have unfolded episodically and that, to achieve maximum benefit they should be orchestrated as a project - in fact, a set of projects-which have yet to be fully defined, assigned, coordinated, monitored and evaluated. Some questions to underscore the point:

- Should we pursue other OEM relationships? (With what manufacturers? Honda, GM, Ford, and Mercedes, others?) Who should decide, initiate the outreach, and coordinate the qualifying discussions?

- Are there universities, think tanks, and grant makers with which we should affiliate?

- What platforms should be in scope for a program aimed at migrating from combustion engine vehicles (retrofits, light trucks \& transports, neighborhood electric vehicles (NEVs), fuel cell vehicles, CNG vehicles, personal mobility vehicles (PMVs)

- Who is responsible for engaging and informing the public?

- How do all the growing number of activities get orchestrated ... and all the interested parties remain informed?

- What are the benchmarks and performance measures that would allow Oregon to know if it is succeeding with its plans?

- How are these vehicles integrated into the social fabric and the built environment (urban and rural?)

- And, ultimately, what is Oregon's end game? Merely to ready itself for new vehicles and infrastructure? Or, to take aggressive, nimble, and purposeful action that will allow our state to be recognized as a center of innovation for sustainable mobility?

\section{$\underline{\text { Recommended Response }}$}


Create a project office to assist in developing strategies, plans, and knowledge bases to rigorously foster the growing array of initiatives and relationships involved in creating low- and no-emission vehicles and other sustainable mobility innovations.

\section{Description}

The goal of the program office is to provide continuous attention and support to the growing range of EV projects and players in our state. The intent is not to control these activities, but to exercise helpful behaviors to various parties in the form of assistance; research and analysis; connecting people; consolidating and leveraging resources; promoting ideas and education; capturing and sharing information and knowledge; and, providing opportunities for learning and dialogue.

Functionally the program office will focus on these several areas:

- Assembling the portfolio of $\mathbf{E V}$ relationships within and outside of Oregon that will help us advance our objectives

- Monitoring the portfolio of $\mathbf{E V}$ projects to ensure that our progress is deliberate and timely

- Cataloging the portfolio of public policy and research questions that must be identified and addressed as we begin our transformation to low- and no-emission vehicles

- Delivering the portfolio of education, training, and information exchanges that are key to our organizational capacity and proficiency in adopting new EV technologies

- Maintaining and availing a knowledge base of case studies, briefing papers, and lessons learned

- Creating a “Living Laboratory” which students and faculty can experience, evaluate and research EVs in the urban environment.

\section{Hosting the Program Office}

Portland State University has prepared a proposal and sought funding for a program office to begin operation in July 2009. The rationale for hosting is based on several considerations. First, part of PSU's mission is to serve as impartial convener for urban issues and innovations. This role is exemplified in the PSU motto: Let Knowledge Serve the City. Second, the University has in place many of the assets to support the program office and it intends to enlist three key organizations for the effort:

- Oregon Transportation Research and Education Consortium (OTREC), a National University Transportation Center, is a partnership between Portland State University, the University of Oregon, Oregon State University, and the Oregon Institute of Technology. With a grant from the U.S. Department of Transportation, OTREC sponsors research, education and technology transfer projects at our partner universities. OTREC supports innovations in sustainable transportation through Advanced Technology, Integration of Land Use and Transportation, and Healthy Communities. OTREC is dedicated to 
stimulating and conducting collaborative multi-disciplinary research on multi-modal surface transportation issues, educating a diverse array of current practitioners and future leaders in the transportation field, and encouraging implementation of relevant research results.

- Hatfield School of Government's Executive Leadership Institute promotes citizen engagement, democratic governance, and policy analysis by extending the School's public service education mission to elected officials and career administrators at offcampus locations throughout the region.

- Hatfield School of Government's National Policy Consensus Center/Oregon Solutions grew out of the State of Oregon's Sustainability Act of 2001. Oregon Solutions has promoted a new style of community governance based on the principles of collaboration, integration, and sustainability. 


\section{Appendix D}

\section{THE FUTURE OF URBAN MOBILITY: PORTLAND STATE UNIVERSITY'S TRANSPORTATION ELECTRIFICATION INITIATIVE STRATEGIC PLAN}

\subsection{OVERVIEW}

Portland State University (PSU)'s Transportation Electrification Initiative will be a cross-campus effort for innovative research and education exploring the electrification of transportation and the integration with the built environment. The Initiative will explore the nexus of the future of sustainable energy, transportation and the built environment by answering questions on consumer behavior, grid integration, and vehicle use \& performance. The Initiative will serve the region by identifying, field-testing, and generalizing knowledge about the practicality and suitability of promising mobility strategies, technologies, services, and practices related to electrification.

Initiative will employ a 'living laboratory' approach where faculty and students can use local settings and organizations to research, evaluate and experience EVs in the urban environment. This research will lead to practical policy and technical guidance to the state and nation, to help address questions on transportation electrification and the development of a smart mobility system within a smart grid.

The Initiative will build research capacity within PSU and will support faculty and students as they plan for, field test, evaluate, experience and report on transportation electrification. PSU has a strong core of researchers actively engaged in sustainable transportation, renewable energy and built environment research, including faculty in engineering, business, urban studies and planning, architecture, computer science, social sciences, and policy. The challenge will be to enlist this expertise and focus it towards the Initiative.

Given the current state of the field and the expertise at PSU and partner universities, the likely areas of focus will include:

- Vehicle design, performance \& use;

- Integration of infrastructure systems with the built environment;

- Markets, vehicle use \& consumer behavior; and

- Evaluation, including societal and lifecycle environmental impacts.

Our intent is to generate a strong understanding and solid foundation of knowledge for the general public, companies and governmental agencies analyzing the new technology, investment and policy options.

This effort will be collaborative and cross-disciplinary, drawing on various public and private partnerships to deliver research, exchange information, educate, and train. It is anticipated that local partners (e.g., state agencies, utilities, local companies and related industries), national players (e.g., federal agencies, national labs, auto companies and related industries) and other national and international universities will be enlisted in the various projects. 


\subsection{OBJECTIVES}

The goal for the first year of this Initiative is to support the creation of a unifying strategic plan for the PSU. The specific objectives are to:

- Develop an internal project team to foster the Initiative;

- Conduct research with quick results in the short-term, setting the stage for longer-term research;

- Publish research, white papers, and use cases;

- Attract partnerships and create opportunities for external funding.

- Build research capacity at PSU and collaboration among OUS campuses, including bring in new disciplines to focus on transportation electrification;

- Align with state and regional efforts; and

- Capitalize and enlarge the current transportation electrification and renewable energy momentum in Oregon and the Northwest.

\subsection{RECOMMENDED ACTIONS}

\subsubsection{Establish Initiative Steering Group and Project Team}

The effort should be guided by a small team (3-5) of leaders from within PSU, including the Maseeh College of Engineering \& Computer Science (MCECS), Office of Research and Strategic Partnerships, and the Oregon Transportation Research and Education Consortium (OTREC). The Steering Group would meet regularly to guide and coordinate all efforts. PSU should also create a larger project team that would be made up of interested faculty and staff from various departments on campus. The goal of the project team is to provide continuous attention and support to the growing range of EV projects and players in our state. The intent is not to control these activities, but to coordinate and facilitate, connect people, consolidate and leverage resources, promote ideas and education, share information and knowledge, and provide opportunities for learning and dialogue. The project team should focus on these several areas:

- Assembling the portfolio of EV relationships within and outside of Oregon that will help us advance our objectives

- Monitoring the portfolio of EV projects to ensure that our progress is deliberate and timely

- Cataloging the portfolio of public policy and research questions that must be identified and addressed as we begin our transformation to low- and no-emission vehicles

- Identifying a range of research projects that address regional, state, and nation issues

- Delivering the portfolio of education, training, and information exchanges that are key to our organizational capacity and proficiency in adopting new EV technologies

- Maintaining and availing a knowledge base of case studies, briefing papers, and lessons learned

- Creating a "Living Laboratory" which students and faculty can experience, evaluate and research EVs in the urban environment. 


\subsubsection{Focus on Short-term Research to Take Advantage of Key Opportunities}

There are several research areas for PSU to move forward on quickly, to take advantage of some timely opportunities:

- Evaluating vehicle performance and driver behavior/use for the EVproject.com (Nissan/Ecotality), Toyota PHEV Prius Demo Project and Mitsubishi iMiEV

- Urban freight use

- Infrastructure planning

- DC fast charging evaluation

- Conduct public opinion surveying to establish baseline information on attitudes and knowledge.

OTREC is supporting some of this start-up research in the area of driver behavior, though more needs to be done. Table 1 list a more detailed description of current key projects and research opportunities for PSU to start to developing research plans and projects.

PSU should also develop a series of white papers to help answer questions partners have on a variety of topics and bring attention to PSU. Potential topics include:

- What are the business cases scenarios for charging stations?

- Develop a technology roadmap assessment for EV business cluster for Oregon

- Conduct policy analysis of EV adoption and GHG reductions goals

- What are the potential of V2G opportunities in the Portland and Oregon?

- Use of DC fast charging in an urban environment

- Economic analysis of Time-of-Use rates

- What does a city need to do to be plug-in ready?

- Can urban freight or fleet be electrified?

- What performance measures for gauging the success of EVs?

\subsubsection{Develop a Long-Term Research Direction}

The long-term strategy should begin with an analysis of the current and ongoing landscape of EV related research, development and demonstration efforts in Oregon, around the United States and the rest of the world. The EV field is a rapidly growing and changing area with many research entities and small companies entering the field. As such, it is challenging to keep up-to-date with the constantly changing field. After evaluating the ongoing research, a SWOT analysis will be completed to find the holes in on-going research and to find opportunities where the state of Oregon can have an impact on EV research, development and demonstration. The research will likely focus on four areas:

1. Vehicle Design, Performance and Use

Vehicle monitoring

Battery performance testing

Battery technology

Powertrain Systems

Communications and IT Support 


\section{Integration with the Built Environment}

Renewable energy storage and systems

Grid capacity and connections

Infrastructure planning and modeling

Charging methods and infrastructure evaluation

Urban design of stations and parking

Communications and IT Support

3. Markets, vehicle use \& consumer behavior

Market surveying and analysis

Consumer demand analysis

Use and behavior evaluations

\section{Evaluation}

Economic and environmental analysis

Governance and policy analysis

Because of the cross-disciplinary needs of the Initiative, PSU will need to engage a variety of departments and faculty. Appendix 1 lists the potential research focus areas and the disciplines and faculty that could potentially be enlisted in research.

\subsubsection{Identify Resource Gaps}

While PSU has many faculty with expertise in the research areas identified, many of those faculty are already committed to full research agendas. Expanding their research portfolio to include transportation electrification will require resources, such as $\mathrm{PhD}$ student fellowships and post-docs. In addition, there are likely gaps in existing expertise that will need to be filled with new faculty and researchers.

\subsubsection{Develop Partnerships and Collaboration}

The Initiative intends to enlist faculty, students, stakeholders, public agencies, organizations, utilities, and electric vehicle-related companies to deliver multidisciplinary solutions for real world problems. PSU already benefits from strong ties to key transportation agencies (including ODOT, City of Portland, TriMet, the Port of Portland, Metro, etc.), electrical utilities, and the transportation industry, including non-profit groups. The Initiative will work very closely the state agencies and cities and will actively pursue collaboration with local partners and national players will be enlisted in the various projects.

PSU will build on already exiting strategic alliances with Portland General Electric (PGE), which focuses on working together on research, economic development, community projects, and professional training aligned with two main themes: "Urban Mobility" and "Integration of Energy and Sustainable Design.” Additionally, PSU has developed a firm relationship with Toyota Motors, which has brought ten Plug-in EV Prius to Oregon for a demonstration project. It will be crucial for PSU to focus on nurturing and establishing external partnerships. By formalizing these relationships, PSU will be able to develop opportunities for faculty to conduct research. The partnership between PGE and Toyota Motors is a great model for forging 
additional partners. Additional partners engaged and interested in the electrification initiative include:

- State agencies (ODOT and ODOE) and local municipalities

- Federal agencies (DOE, DOT and INL)

- Utilities (e.g., PGE, Salem Electric, EWEB, PacifiCorp)

- Drive Oregon (Oregon EV Business cluster) \& Oregon EV Association

- Auto companies (national \& local): Nissan, Toyota, Mitsubishi, Ford, GM, Daimler, BMW, VW, Freightliner, etc.

- Charging station companies: ECOtality, Coulomb, NEC, Shorepower

- Other related industries (Zipcar, Google, Intel, IBM)

There are also opportunities to establish partnerships with other universities and institutions.

Table 2 lists the current opportunities PSU has been developing both nationally and internationally.

\subsection{THE LARGER AGENDA FOR THE FUTURE OF URBAN MOBILITY}

Transportation electrification is just one aspect of PSU's effort to understand, guide, and lead innovation regarding urban mobility. Other efforts are underway at these entities:

- Initiative for Bicycle and Pedestrian Innovation (IBPI)

- Intelligent Transportation Systems (ITS) Laboratory

- Oregon Modeling Collaborative

- Oregon Transportation Research and Education Consortium

- Center for Urban Studies and Center for Transportation Studies 
Table 1: Current Key Projects and Research Opportunities

\begin{tabular}{|c|c|c|}
\hline CATEGORY & PROJECT NAME & COMMENTS \\
\hline TIER 1 & DC Fast Charge Project & Explore opportunities and potential use for DC Fast changing with PGE \\
\hline TIER 1 & Toyota Plug-in Prius Demo Program & PSU has ten Plug-in Prius for demonstration for one year. Develop a comprehensive research plan. \\
\hline TIER 1 & $\begin{array}{l}\text { Quick Charger and Mitsubishi iMiEV } \\
\text { Research }\end{array}$ & $\begin{array}{l}\text { 90-days of possible use. Partnership with PGE. Consider documenting L3 recharging scenarios from } \\
\text { depleted state to charge level after } 5 \text { minutes, 10, 12, 15, 20, and } 25 \text { minutes (could affect how to } \\
\text { price). Also document range performance of } 60 \text { miles driving on flat surface streets, on I-5, on I-84 } \\
\text { in a head wind, and in cold weather under } 50 \text { degrees, } 40 \text { degrees, and } 20 \text { degrees. }\end{array}$ \\
\hline TIER 1 & Conduct Public Opinion Research & $\begin{array}{l}\text { Consumer knowledge and public opinion data is extremely important to craft an outreach and } \\
\text { education campaign. A market acceptance and opinion polling and analysis. PSU should baseline } \\
\text { consumer knowledge and opinions about the technology. }\end{array}$ \\
\hline TIER 1 & Green Highway Fast Charge Network & $\begin{array}{l}\text { ODOT has received a TIGER II grant to develop a fast charging network in Oregon and electrifying } \\
\text { I-5 for Portland to California. OTREC is named as a partner on research. }\end{array}$ \\
\hline TIER 2 & $\begin{array}{l}\text { Phase Two Architecture for Oregon's } \\
\text { Public Charging Network }\end{array}$ & Model potential scenarios for charging station infrastructure. \\
\hline TIER 2 & Data Access and Collection & $\begin{array}{l}\text { PSU can be the warehouse of EV information for the region. This data would include infrastructure } \\
\text { locations, use data, vehicle travel and behavior data. Need to partner with Ecotality to obtain data. }\end{array}$ \\
\hline TIER 3 & Create a statewide demo project & $\begin{array}{l}\text { Support for a statewide demonstration project that includes testing vehicles and gathering data of } \\
\text { vehicles, charging infrastructure and individuals' behaviors. }\end{array}$ \\
\hline TIER 3 & EV Zipcar Project & Prius Plug-in Zip Car will be placed at PSU \\
\hline TIER 3 & EV Cabs Project & Interest from Yellow Cab and Broadway Cab. \\
\hline TIER 3 & $\begin{array}{l}\text { Electrification of Urban Freight and } \\
\text { Service Vehicles (light-to-medium } \\
\text { duty trucks) }\end{array}$ & Potential demonstration project with Navistar, Smith and Freightliner \\
\hline TIER 3 & EV Rental Car Initiative & Portland of Portland-PSU-Travel Oregon initiative with Hertz, Avis, and Enterprise \\
\hline
\end{tabular}

Tier 1 - Current opportunity; Tier 2 - Potential opportunity or need; Tier 3 - Project ideas that need further development 


\begin{tabular}{|c|c|c|c|c|c|}
\hline Partnership & Description & Funding & PSU Areas Focus & Benefits & Next Steps \\
\hline \multicolumn{6}{|l|}{ University Partnerships } \\
\hline $\begin{array}{l}\text { NSF-I/UCRC: } \\
\text { University of Texas } \\
\text { and Texas A\&M }\end{array}$ & $\begin{array}{l}\text { Center for Transportation and Electricity } \\
\text { Convergence }\end{array}$ & $\begin{array}{l}\text { Memberships: } \\
\text { \$160,000/year for } 5 \\
\text { years; NSF } \\
\text { \$55,000/year for } 5 \\
\text { years. Potential of } \\
\text { match by OTREC } \\
\text { funds. }\end{array}$ & $\begin{array}{l}\text { Initial areas: urban freight } \\
\text { \& logistics and consumer } \\
\text { behavior. Other areas in } \\
\text { EV and grid research }\end{array}$ & $\begin{array}{l}\text { NSF prestige. } \\
\text { Collaboration } \\
\text { with two } \\
\text { nationally } \\
\text { known } \\
\text { universities }\end{array}$ & $\begin{array}{l}\text { Submit a Letter of Intent } \\
\text { by Jan 1., } 2011 \text { and raise } \\
\text { commitments for } \\
\text { membership }\end{array}$ \\
\hline $\begin{array}{l}\text { Clemson University: } \\
\text { CU-ICAR }\end{array}$ & $\begin{array}{l}\text { CU-ICAR is an advanced-technology research } \\
\text { campus where academia, industry and } \\
\text { government organizations engage in synergistic } \\
\text { collaboration. CU-ICAR represents } \\
\text { public/private partnership, focusing on areas: 1) } \\
\text { Automotive Design \& Development 2) } \\
\text { Manufacturing 3) Automotive Systems } \\
\text { Integration 4) Vehicle Electronic Systems } \\
\text { Integration. The partnership would create a west } \\
\text { coast arm of ICAR. }\end{array}$ & $\begin{array}{l}\text { No specific funding } \\
\text { details }\end{array}$ & $\begin{array}{l}\text { Areas of collaboration } \\
\text { have not been determined. } \\
\text { Potential areas could be in } \\
\text { vehicle use and testing, } \\
\text { mobility evaluation, } \\
\text { alternative vehicle design, } \\
\text { etc. }\end{array}$ & $\begin{array}{l}\text { National } \\
\text { relationships } \\
\text { and } \\
\text { collaboration } \\
\text { with a well- } \\
\text { regarded } \\
\text { university }\end{array}$ & $\begin{array}{l}\text { Meet with ICAR } \\
\text { leadership and develop a } \\
\text { MOU }\end{array}$ \\
\hline Waseda University & $\begin{array}{l}\text { Exploring possible relationships with Waseda } \\
\text { University. }\end{array}$ & $\begin{array}{l}\text { No specific funding } \\
\text { details }\end{array}$ & $\begin{array}{l}\text { Smart Grid and electric } \\
\text { vehicles. Potential focus } \\
\text { could be on Ecodistricts. }\end{array}$ & $\begin{array}{l}\text { International } \\
\text { collaboration. } \\
\text { Relationships } \\
\text { with Japanese } \\
\text { OEMs }\end{array}$ & $\begin{array}{l}\text { Develop a MOU. Have a } \\
\text { workshop for } \\
\text { information exchange. } \\
\text { Exchange students and } \\
\text { faculty. }\end{array}$ \\
\hline $\begin{array}{l}\text { University of } \\
\text { California - Davis }\end{array}$ & $\begin{array}{l}\text { UC-Davis has a well established PHEV program } \\
\text { and is a part of The EV Project } \\
\text { (Nissan/Ecotality). }\end{array}$ & $\begin{array}{l}\text { No specific funding } \\
\text { details }\end{array}$ & $\begin{array}{l}\text { Collaborative } \\
\text { transportation research. } \\
\text { Demonstration projects }\end{array}$ & $\begin{array}{l}\text { National } \\
\text { relationships } \\
\text { and } \\
\text { collaboration } \\
\text { with a well- } \\
\text { regarded } \\
\text { university }\end{array}$ & $\begin{array}{l}\text { Reach out to establish } \\
\text { relationship }\end{array}$ \\
\hline $\begin{array}{l}\text { China: Tongji } \\
\text { University }\end{array}$ & $\begin{array}{l}\text { Establish a relationship with a Chinese } \\
\text { university. PSU already has discussions with } \\
\text { Tongji University. Tongji U. recently developed } \\
\text { an EV Research Center and established a } \\
\text { relationship with Audi and some German } \\
\text { universities. There is also a project ZEV Special } \\
\text { Development Zone for Shanghai Chongming } \\
\text { Island. }\end{array}$ & $\begin{array}{l}\text { No specific funding } \\
\text { details }\end{array}$ & Collaborative research & $\begin{array}{l}\text { International } \\
\text { collaboration. } \\
\text { Relationships } \\
\text { with Chinese } \\
\text { OEMs }\end{array}$ & $\begin{array}{l}\text { Use existing connections } \\
\text { to explore possibilities. }\end{array}$ \\
\hline
\end{tabular}




\begin{tabular}{|l|l|l|l|l|l|}
\hline Other Research Partnerships & $\begin{array}{l}\text { Oregon Inc. has chosen Drive Oregon, Oregon's million } \\
\text { EV cluster association, to be an industry } \\
\text { innovation center }\end{array}$ & $\begin{array}{l}\text { Collaborative EV research } \\
\text { and commercialization } \\
\text { (mostly related vehicle } \\
\text { technologies) }\end{array}$ & $\begin{array}{l}\text { Develop } \\
\text { relationships } \\
\text { local } \\
\text { companies. }\end{array}$ & $\begin{array}{l}\text { Leg. funding in the 2011 } \\
\text { session. }\end{array}$ \\
\hline Idaho National Labs & $\begin{array}{l}\text { INL is collecting and analyzing data as part of } \\
\text { the EV Project (Ecotality/Nissan) but is } \\
\text { becoming the national data depository. }\end{array}$ & $\begin{array}{l}\text { No specific funding } \\
\text { details }\end{array}$ & EV data collection & $\begin{array}{l}\text { National } \\
\text { relationships } \\
\text { and } \\
\text { collaboration } \\
\text { with a well- } \\
\text { regarded } \\
\text { university }\end{array}$ & $\begin{array}{l}\text { Reach out to establish } \\
\text { relationship }\end{array}$ \\
\hline
\end{tabular}




\subsection{VEHICLE DESIGN, PERFORMANCE, AND USE}

- Vehicle monitoring

Monitoring private EV use \& charge patterns

Monitoring fleet EV use \& charge patterns

Development of EV-specific travel models, by EV type and ownership

Drive experience evaluation

- $\quad$ Battery performance testing

Charging behavior (frequency, charge level used) effect on battery lifespan and range.

Driving characteristics on battery lifespan and range.

Weather effect on battery lifespan and range.

- Battery technology

Materials development for future battery technology

Nanotechnology development for future battery technology

- Powertrain Systems

- Communications and IT Support

Smart Mobility Hub and Intellidrive component development \& implementation

Systems development

Analysis of factors for determining range

Accuracy of range forecasting techniques

Initiate "Connected Car" program

Faculty:

Jennifer Dill (CUPA - USP) http://web.pdx.edu/ jdill/

Research: Travel behavior, transportation and land use policy

Chris Monsere (CECS - CEE) http://web.cecs.pdx.edu/ monserec/

Research: Transportation safety, freight transportation, traffic operations

Miguel Figliozzi (CECS - CEE) http://www.cee.pdx.edu/faculty/figliozzi.php

Research: Impact of congestion on commercial vehicle movements.

Kelly Clifton (CECS- CEE) http://kellyjclifton.com/

Research: Transportation survey methods, travel behavior, travel planning \& policy

Faryar Etesami (CECS - MME) http://web.cecs.pdx.edu/ far/

Research: Mechanical design; computer-aided design; mechanical tolerancing; and statistical process improvement 
Jim Van Winkle (CECS - MME) http://www.me.pdx.edu/people/index.php?action=12\&uid=42 Research: Metallic and ceramic corrosion and electrochemistry; thin films; semiconductor manufacturing

Dave Turcic (CECS - MME) http://www.me.pdx.edu/people/index.php?action=12\&uid=35 Research: Analysis and design of high speed mechanical systems; system design; motion synthesis for manufacturing and material handling processes; design for manufacturing, robotics, computer aided design and computer-aided manufacturing; geometric modeling; automatic controls; and experimental methods

James Woods (CLAS - Economics) http://www.pdx.edu/econ/james-woods

Research: Teaches engineering economics, research in household conservation behavior

Richard Tymerski (CECS - ECE) http://web.cecs.pdx.edu/ tymerski/

Research: Power electronics \& control

Paul Van Halen (CECS - ECE) http://web.cecs.pdx.edu/ vanhalen/

Research: Integrated circuit device physics; modeling; characterization and processing

\subsection{INTEGRATION WITH THE BUILT ENVIRONMENT}

Renewable energy storage and systems

o Analysis of battery second life programs

- Advanced solar energy capture and charging systems

o Renewable energy storage battery development

Faculty:

Carl C Wamser (CLAS - Chemistry) http://www.chem.pdx.edu/\%7Ewamserc/

Research: Solar energy conversion, using artificial photosynthesis.

Wayne Rifer (SBA - MIM Specialization instructor) http://www.pdx.edu/sba/fp-wayne-rifer (Also: http://sustain.uoregon.edu/workshops/reg_instructor.php?instructorid=513510)

Work: Battery Recycling, Product Stewardship, Waste management

$>$ Grid capacity and connections

o Peak load scenario analysis and management strategy

- Temporal load analysis forecasting by market share penetration

o Consumer choices regarding charging, time of day and location.

- Grid system connection and monitoring

- Analysis of EV user participation in voluntary green power programs

- Impact EV market share on electricity energy prices

\section{Faculty:}

David J. Sailor (CECS-MME) http://web.cecs.pdx.edu/ sailor/

Research: Urban climate measurements and modeling; characterization of the urban heat island and assessment of mitigation potential; building energy efficiency and green building technologies; regional and local climate interactions with energy systems; including impacts on demand and renewable resources 
Loren Lutzenhiser (CUPA - USP) http://www.pdx.edu/usp/profile/meet-professor-loren-

lutzenhiser

Research: Energy use and global warming; household energy consumption practices

Dan Rogers (SBA - Finance) http://www.pdx.edu/sba/fp-dan-rogers

Research: Corporate Risk Management, particular history with Jet Fuel hedging

(See Also Jeff Hammarlund in Section IV)

$>$ Charging methods and infrastructure evaluation

o Estimating private charging availability on metropolitan-scale

o Charging usage scenario planning

- Public charging location/allocation GIS model w/ sensitivity analysis

- Evaluation of decisions factors for corporate sponsoring of public charging.

- Evaluation of ROW, locate, liability issues in public charging. Who bears costs and risks?

Faculty:

John Gliebe (CUPA - USP) http://www.pdx.edu/profile/meet-professor-john-gliebe

Research: Travel demand modeling

Scott Marshall (SBA - Management) http://www.pdx.edu/sba/fp-scott-marshall

Research: proactive environmental strategy, corporate governance, sustainability reporting, and environmental and social multi-stakeholder initiatives

Darrel Brown (SBA - Accounting) http://www.pdx.edu/sba/fp-darrell-brown

Research: Corporate social and environmental reporting, the relationship business reporting and business transparency, and the relationship between social and environmental reporting and firm performance.

Jiunn-Der (Geoffrey) Duh (CLAS - Geography) http://web.pdx.edu/ jduh/

Research: GIS, spatial decision support systems, landscape ecology, socioeconomic processes

$>$ Urban design of stations and parking

- Evaluation of barriers to time reserve charging options

o Design options for on-street charging (identification, safety, ease of use)

- Design options for commercial facility retrofitting of EV charging

o Impact of designated EV park/charge reserved on-street parking

- Design of solar charging stations

Faculty:

James Strathman (CUPA - USP) http://www.upa.pdx.edu/CUS/about/meetthedirector.html Research: Transit operations, roadway supply, parking behavior \& policies

Thomas Harvey (CLAS - Geography) http://web.pdx.edu/ harveyt/ Research: Urban geography, cultural landscape studies, sustainable cities

L. Rudolph Barton (Fine Arts - Architecture) http://www.pdx.edu/architecture/faculty-barton Research: No research listed, sits on Sustainable Urban Development Board.

Graig Spolek (CECS - MME) http://web.cecs.pdx.edu/ graig/ Research: Performance measurement and design of green roof systems; HVAC systems design and control; industrial drying; and industrial energy utilization 
$>$ Communications and IT Support

o Charging Station information protocols (availability, usage, location, error analysis)

o User information privacy risk/protection at charging stations

\section{Faculty:}

Nirupama Bulusu(CECS- CS) http://web.cecs.pdx.edu/ nbulusu/

Research: sensor networks; cyber-physical systems; environmental and urban sensing

Suresh Singh (CECS - CS) http://web.cecs.pdx.edu/ singh/

Research: Wireless networks, performance evaluation, protocol design

Kristin Tufte (CECS - CS) http://web.cecs.pdx.edu/ tufte/

Research: Data Stream management, application of database technology problems to ITS

Yih-Chyu (Y.C.) Jenq (CECS - CS) http://web.cecs.pdx.edu/ jenq/

Research: Communications and digital signal processing

Melinda Holtzman (CECS - CS) http://www.ece.pdx.edu/Faculty/Holtzman.php

Research: Electromagnetics; semiconductor materials and devices; mobile sensors

Erica Wagner (SBA) http://www.pdx.edu/sba/fp-erica-wagner

Research: Information systems

\subsection{USE AND CONSUMERS}

$>$ Market surveying and analysis

- Consumer perception of EV Value (vs non-EV available products)

o Consumer acceptance and demand for EV in car share market

- Public interpretation of EV news and product marketing

o Public perception of state government role in EV strategy

$>$ Consumer demand analysis

o Understanding choices towards purchase based on lifecycle vs. initial costs

- Analysis of public charging payment options

o Analysis of factors influencing solar charging demand

$>$ Use and behavior evaluations

o Multiple-vendor charging scenario implication for EV users

Faculty:

Jill Mosteller (SBA-Marketing) http://www.pdx.edu/sba/fp-jill-mosteller

Research: Consumer decision making

L. P. Douglas Tseng (SBA - Marketing) http://www.pdx.edu/sba/fp-douglas-tseng Research: Consumer Choice modeling, decision making, market research

Duncan Kretovich (SBA - Finance) http://www.pdx.edu/sba/fp-duncan-kretovich Research: Corporate finance, working capital, personal financial planning, cash management.

Neil Ramiller (SBA - Information Systems) http://www.pdx.edu/sba/fp-neil-ramiller Research: Rhetoric, narrative, discourse in information technology 
Robert B. Harmon (SBA - Marketing) http://www.pdx.edu/sba/fp-robert-harmon Research: technology marketing consultant, product life-cycle management, pricing strategy

Alan J. Reskik (SBAA - Marketing) http://www.pdx.edu/sba/fp-alan-resnik Research: Strategy Planning, Market segmentation

Veronica Dujon (CLAS - Sociology) http://www.sociology.pdx.edu/faculty/Dujon/research.php Research: Environmental sociology, globalization

Cynthia Mohr (CLAS - Psychology) http://www.pdx.edu/psy/cynthia-mohr/ Research: Social psychology, behavior change

\subsubsection{Evaluation}

$>$ Economic and environmental analysis

o Utility cost recovery models

- Time and usage-based pricing models

- Impact of EV market share on Metro/State VMT goals

o Interaction of EV choice vs. other non vehicle use choices

- GHG reduction estimates, refinement of forecasts with observed data

- Evaluating non-GHG emission reduction

- Estimating EV market share needed for air-quality improvements in metro area

- Innovation analysis of Oregon EV start-ups

- Analysis of factors leading to growth in solar industry from increased EV market share

o Evaluation of opportunities for workforce development

Faculty:

Melissa Appleyard (SBA-Management) http://www.pdx.edu/sba/fp-melissa-appleyard Research: Innovation and process design in Silicon Valley

Jorge Walter (SBA - Management) http://www.pdx.edu/sba/fp-jorge-walter

Research: Strategic decision making, tech transfer in context of entrepreneurs, inter-firm alliances, high- tech industries

Vivek Shandas (CUPA - USP) http://web.pdx.edu/ vshandas/

Research: Environmental policy, GIS, natural resource management, participatory planning, urban ecology

David Ervin (CLAS - Environmental Science \& mgmt) http://web.pdx.edu/ dervin/ Research: Environmental management, environmental policy reform, green business

Linda George (CLAS - Environmental Science \& Mgmt) http://web.pdx.edu/ h6lg/ Research: Monitoring \& modeling of urban air pollutants, assessing human exposure to and perception of air pollutants and climate change, linking health \& traffic

Aslam Khalil (CLAS - Physics) http://www.physics.pdx.edu/ aslamk/aslamk/ Research: Directs Global Change Research Program, studying sources and characteristics of urban air pollution; long term global effects of man-made pollutants.

Randall A. Bluffstone (CLAS - Economics) http://www.pdx.edu/econ/randall-bluffstone Research: Environmental and resource economics including pollution policies in developing and transition economies, environmental livability and privatization. 
Dave Garten (SBA - instructor) http://www.pdx.edu/sba/fp-dave-garten

Background: Business strategy, with alt fuels and automotive background

David Raffo (SBA - Supply \& Logistics Mgmt) http://www.pdx.edu/sba/fp-david-raffo Research: Economic Analysis of engineering decisions / Business Case development

$>$ Governance and policy analysis

o Utility alternative fuel policy evaluation

- Evaluation of Public Utility Commission policy towards charging infrastructure

- Analysis of efficacy of government provided incentives towards EV users

- Analysis of efficacy of government provided incentives towards EV manufacturing

- Cost benefit Analysis of Smart Grid implementation

- Analysis of EV contributions to State \& Metro economic development

- EV impact on state and federal transportation funding options

- Evaluation of methods to secure revenue from EV usage for transportation funding

- Public and stakeholder benefit analysis

- Oregon leadership example in EV strategy

- Analysis of considering EV towards Utility renewable portfolio standards

o Analysis of government fleet EV share standards

- Certification standards for EV conversion kits

o Joint public-private purchasing pools

Faculty:

William J. Kenney (SBA - Accounting)http://www.pdx.edu/sba/fp-william-kenny

Research: Taxation

Jeff Hammarlund (CUPA - ELI) http://www.eli.pdx.edu/staff/bios/bio_jh.php

Focus: Energy Resources and Policy, Planning the Smart Grid for Sustainable Communities, National Policy Process

Anthony Rufolo (CUPA- USP) http://www.pdx.edu/usp/profile/meet-professor-anthony-rufolo Research: State and Local Finance, Transportation, Urban Economics, and Regional Economic Development

Gerard Mildner (SBA-Real Estate)

Research: Economics of local government, public finance, cost-benefit analysis, growth management, rent control, municipal sports stadiums, housing markets, land use regulation, and urban transportation.

Connie Ozawa (CUPA - USP) http://web.pdx.edu/ ozawac/

Research: use of scientific and technical information in public decision-making, the role of the professional, public participation methods.

Daniel Monroe Sullivan (CLAS - Soc.) http://www.sociology.pdx.edu/faculty/Sullivan/index.php Research: Urban neighborhoods, gentrification, racial \& socio-economic segregation/integration. Social research methods

John F. Walker (CLAS - Economics) http://www.pdx.edu/econ/john-f-walker Research: American Economic History, Productivity Analysis, Government Spending

Craig Shinn (CUPA - ELI) http://www.pdx.edu/hatfieldschool/craig-shinn-bs-mpa-phd 
Research: Adaptive management policy, social aspects of sustainability, civic capacity building and inter-jurisdictional administration of natural resources

Jennifer Allen (CUPA - Public Admin) http://www.pdx.edu/sustainability/profile/jennifer-allen Research: environmental and natural resource policy and administration and sustainable economic development 


\subsection{OTHER FACULTY}

\section{Engineering \& Technology Management:}

Dundar F. Kocaoglu (CECS - ETM) http://www.etm.pdx.edu/faculty/kocaoglu1.asp

Research: Decision analysis, technology management, competitive strategies, analytic hierarchy process (AHP), multi-criteria decision-making, project management, emerging technologies

Timothy R Anderson (CECS - ETM) http://www.etm.pdx.edu/faculty.asp\#6

Research: Data Envelopment Analysis (DEA), productivity management, benchmarking; manufacturing management, engineering economy, operations research

Tugrul U. Daim (CECS - ETM) http://www.etm.pdx.edu/faculty.asp\#8

Research: Technology evaluation and forecasting, research and development management, technology transfer, technology roadmapping

Robert D. Dryden (CECS - ETM)

Research: Rehabilitation engineering; construction productivity; human factors engineering; and safety

Antonie J. Jetter (CECS - ETM) http://www.etm.pdx.edu/faculty.asp\#28

Research: Technology and innovation management, new product development, knowledge management, organizational learning

Dragan Milosevic (CECS - ETM) http://www.etm.pdx.edu/faculty.asp\#7

Research: Total quality management, re-engineering; strategic planning; team building, communication, international project management

Paul Newman (CECS - ETM) http://www.etm.pdx.edu/faculty.asp\#33

Research: New product development processes and tools; the evaluation and acquisition of emerging technologies; government roles in developing new products or services; the "pull side" of technology development; managing technological innovation in global settings

Charles M. Weber (CECS - ETM) http://www.etm.pdx.edu/faculty.asp\#17

Research: Innovation management, technological entrepreneurship, new product development, semiconductor industry

Desiree Pacheco (SBA) http://www.pdx.edu/sba/fp-desiree-pacheco

Research: Business strategy and sustainability, Environmental entrepreneurship, Role of institutions on firm strategy, competitiveness, and knowledge creation, Social movements and firm strategy, Institutions and entrepreneurship 


\subsubsection{Table 3: EV Research Area / Department Matrix}

\begin{tabular}{|c|c|c|c|c|c|c|c|c|c|c|c|c|c|c|c|c|c|c|c|c|}
\hline & \multicolumn{4}{|c|}{ CECS } & \multicolumn{3}{|c|}{ CUPA } & \multicolumn{6}{|c|}{ SBA } & \multicolumn{6}{|c|}{ CLAS } & \multirow{2}{*}{ 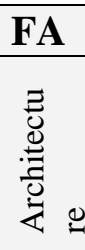 } \\
\hline & $\tilde{u}$ & [I] & $\sum_{\sum}^{1}$ & 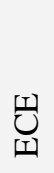 & $\stackrel{ص}{ص}$ & $\overleftrightarrow{\Xi}$ & 苛 & 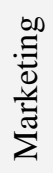 & 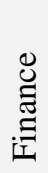 & 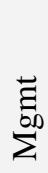 & 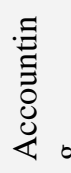 & 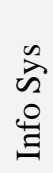 & 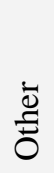 & 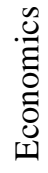 & 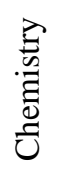 & 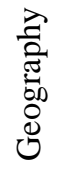 & 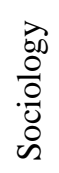 & 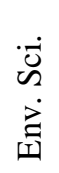 & $\frac{n}{\frac{n}{n}}$ & \\
\hline $\begin{array}{l}\text { I. Vehicle Design, Performance, \& } \\
\text { Use }\end{array}$ & & $\mathrm{X}$ & $\mathrm{X}$ & $\mathrm{X}$ & $\mathrm{X}$ & & & & & & & & & $\mathrm{X}$ & & & & & & \\
\hline $\begin{array}{l}\text { 4.1.2 II. Integration with the } \\
\text { Built environment }\end{array}$ & & & & & & & & & & & & & & & & & & & & \\
\hline Renewable Energy \& Storage & & & $\mathrm{X}$ & & & & & & & & & & & & $\mathrm{X}$ & & & & & \\
\hline Grid Capacity \& Connection & & & $\mathrm{X}$ & & $\mathrm{X}$ & & & & $\mathrm{X}$ & & & & & & & & & & & \\
\hline Charging Methods \& Infrastructure & & & & & $\mathrm{X}$ & & & & & $\mathrm{X}$ & $\mathrm{X}$ & & & & & $\mathrm{X}$ & & & & \\
\hline $\begin{array}{l}\text { Urban Design of charging and } \\
\text { parking }\end{array}$ & & & $\mathrm{X}$ & & $\mathrm{X}$ & & & & & & & & & & & $\mathrm{X}$ & & & & $\mathrm{X}$ \\
\hline Communication \& IT support & $\mathrm{X}$ & & & & & & & & & & & $\mathrm{X}$ & & & & & & & & \\
\hline 4.1.3 III. Use and Consumers & & & & & & & & $\mathrm{X}$ & $\mathrm{X}$ & & & $\mathrm{X}$ & & & & & $\mathrm{X}$ & & & \\
\hline $\begin{array}{ll}4.1 .4 & \text { IV. Evaluation } \\
\end{array}$ & & & & & & & & & & & & & & & & & & & & \\
\hline $\begin{array}{l}\text { Economic \& Environmental } \\
\text { Analysis }\end{array}$ & & $\mathrm{X}$ & & & $\mathrm{X}$ & & & & & $\mathrm{X}$ & & & $\mathrm{X}$ & $\mathrm{X}$ & & & & $X$ & $\mathrm{X}$ & \\
\hline Government and Policy Analysis & & & & & $\mathrm{X}$ & $\mathrm{X}$ & $\mathrm{X}$ & & & & $\mathrm{X}$ & & & $\mathrm{X}$ & & & $\mathrm{X}$ & & & \\
\hline
\end{tabular}

CECS: Maseeh College of Engineering \& Computer Science

CS: Computer Science

CEE: Civil \& Environmental Engineering

MME: Mechanical \& Materials Engineering

ECE: Electrical \& Computer Engineering

CUPA: College of Urban \& Public Affairs

USP: Toulan School of Urban Studies \& Planning

PA: Hatfield School of Government, Public Administration

ELI: Executive Leadership Institute

SBA: School of Business Administration

CLAS: College of Liberal Arts \& Sciences

FA: School of Fine and Performing Arts 
